\title{
Corneal abrasion risk in septorhinoplasty operations under general anesthesia
}

\section{Genel anestezi altında yapılan septorinoplasti ameliyatlarında kornea abrazyonu oluşma riski}

\author{
(D) Ahmet Hamdi Kepekci ${ }^{1}$, (ㄷ) Ali Bestemi Kepekci ${ }^{2}$ \\ ${ }^{1}$ Istanbul Yeni Yuzyil University, Vocational Health High School, Department of Audiometry, Istanbul, Turkey-Meltem Hospital, Department \\ of Otolaryngology, Istanbul, Turkey \\ ${ }^{2}$ Istanbul Yeni Yuzyil University, Vocational Health High School, Department of Anesthesia, Istanbul, Turkey-Meltem Hospital, Department of \\ Anesthesiology and Reanimation, Istanbul, Turkey
}

Cite this article as/Bu makaleye atıf için: Kepekci $\mathrm{AH}$, Kepekci $\mathrm{AB}$. Corneal abrasion risk in septorhinoplasty operations under general anesthesia. J Health Sci Med 2020; 3(4): 427-431.

\begin{abstract}
Aim: Proper care of the eye is required in all anesthetic applications, especially during general anesthesia. Corneal abrasion is the most common ophthalmologic complication in patients undergoing general anesthesia for non-ocular surgery. Corneal protection methods have been developed to reduce and eliminate the rate of this preventable complication. In this study, it was aimed to compare eye closure with hypoallergenic surgical tapes, eye closure with bio-occlusive dressing and antibiotic eye ointment for eye protection in patients undergoing septorhinoplasty under general anesthesia.

Material and Method: The surgical files of all patients with ASA I and ASA II who underwent septorhinoplasty between 1 January 2019 and 31 December 2019 in our hospital were retrospectively analyzed. A total of 721 patients, 403 female, 318 male, were included in the study. The patients were divided into three groups according to the methods used for eye protection. The demographic features of the patients, the duration of the operation and the findings or complaints about the eyes, if any, before and after the operation were listed from the surgery and outpatient files. It was investigated whether the frequency of eye complaints and symptoms had a significant difference between patients with different eye protection methods. $\mathrm{p}<0.05$ was considered statistically significant.

Results: In 721 patients included in the study, it was determined that hypoallergenic surgical tape was applied to 198 patients, an eye ointment with antibiotics was applied to 302 patients, and a bio-occlusive dressing was applied to 221 patients. It was determined that two patients in Group I using hypoallergenic surgical tape and one patient in Group II using antibiotic eye ointment was observed to have a sting and rash that did not require treatment on the first day of the operation. These findings evaluated as CA were not statistically significant between the groups ( $\mathrm{p}=0.264)$.

Conclusion: In septorhinoplasty surgery, there is no significant difference between closing the eyelids directly, applying ointment or closing with bio-occlusive material. However, the bio-occlusive dressing can be used in patients at risk of corneal pathology.
\end{abstract}

Keywords: Bio-occlusive dressing, corneal abrasion, eye care, eye protection, general anesthesia, peri-operative eye injury

\section{ÖZ}

Amaç: Tüm anestezik uygulamalarda, özellikle genel anestezi uygulanması sırasında gözün uygun bakımı gereklidir. Nonoküler cerrahi için genel anestezi uygulanan hastalarda en sık görülen oftalmolojik komplikasyon kornea hasarıdır. Bu önlenebilir komplikasyonun oranını azaltmak ve ortadan kaldırmak için kornea koruma yöntemleri geliştirilmiştir. Bu çalışmada genel anestezi altında septorinoplasti uygulanan hastalarda göz korunması amacıyla hipoallerjenik cerrahi flasterle göz kapatma, biyo-oklüzif şeffaf bantla göz kapatma ve antibiyotikli göz pomadı uygulanmasının karşılaştırılması amaçlanmıştır.

Gereç ve Yöntem: Hastanemizde 1 Ocak 2019/31 Aralık 2019 arasındaki Septorinoplasti yapılmış ASA I ve ASA II olan tüm hastaların ameliyat dosyaları retrospektif olarak incelendi. 403 kadın 318 erkek toplam 721 hasta çalısmaya dahil edildi. Hastalar, göz koruma için kullanılan yöntemlere göre 3 gruba ayrıldı. Ameliyat ve poliklinik dosyalarından hastaların demografik özellikleri, operasyon süreleri, operasyondan önce ve operasyondan sonraki dönemde varsa gözleri ile ilgili bulgu ya da şikâyetleri listelendi. Göz şikâyet ve bulgularının görülme sıklığının farklı göz koruma yöntemleri uygulanan hastalar arasında anlamlı bir farkları olup olmadığı araştırıldı. İstatiksel olarak p $<0,05$ anlamlı olarak kabul edildi.

Bulgular: Çalışmaya dahil edilen 721 hastada göz koruma yöntemi olarak 198 hastaya nonallerjik flaster, 302 hastaya antibiyotikli göz pomadı, 221 hastaya biyo-oklüzif şeffaf bant uygulandığı tespit edildi. Nonallerjik flaster kullanılan Grup I'de 2 ve antibiyotikli göz pomadı kullanılan Grup II'de 1 hastada operasyonun 1. gününde tedavi gerektirmeyen batma ve kızarıklık görüldüğü tespit edildi. CA olarak değerlendirilmiş olan bu bulgular gruplar arasında istatiksel olarak anlamlı değildi $(\mathrm{p}=0,264)$.

Sonuç: inoplasti cerrahisinde göz kapaklarını doğrudan bantlayarak kapatmak, merhem sürmek veya biyooklüzif malzeme ile kapatmak arasında anlamlı bir fark yoktur. Ancak kornea patolojisi riski olan hastalarda biyo-oklüzif şeffaf bantlar kullanılabilir.

Anahtar Kelimeler: Bio-occlusive șeffaf bant, genel anestezi, göz bakımı, göz koruması, kornea hasarı, perioperarif göz yaralanması 


\section{INTRODUCTION}

Proper care of the eye is required in all anesthetic applications, especially during general anesthesia. Corneal abrasion (CA) is the most common ophthalmologic complication in patients undergoing general anesthesia for non-ocular surgery (1). CA is defined as a defect on the epithelial surface of the cornea, the anterior part of the eye (2).

Patients complain of eye pain, blurred vision, headache, discomfort during blinking or opening, excessive tearing, light sensitivity, feeling of sand, stinging and foreign body sensation. Factors contributing to the formation of CA can be direct irritation of the cornea with a chemical substance, as well as the lack of protective corneal reflex during operation and a decrease in basal tear production can be counted as the main reasons (3).

In rare cases, direct trauma to the eye with mask and laryngoscope, head and neck operations and operations other than the supine position of the patient can be counted among other reasons (4).

Visual loss secondary to trauma or irreversible corneal opacification has been reported after chemical injury during general anesthesia (5).

Various methods have been proposed for peri-operative ocular surface protection. These are manual closure of closed eyelids with or without eye ointment with tapes, application of oil-based lubricant ointments, aqueous solutions such as methylcellulose or viscous gels, wearing protective glasses, wearing hydrophilic contact lenses, tarsore sutures, geliperm dressing (5).

There are studies showing the prevalence of CA between $0.01 \%$ and $59 \%$ during non-ocular surgery $(6,7)$.

Rhinoplasty is one of the most commonly performed cosmetic procedures around the world (8). In literature searches, no study on the frequency of CA was found during rhinoplasty surgeries.

Corneal protection methods have been developed to reduce and eliminate the rate of this potentially preventable complication.

In this study, it was aimed to compare eye closure with hypoallergenic surgical tape, eye closure with bioocclusive dressing and antibiotic eye ointment for eye protection in patients undergoing rhinoplasty under general anesthesia.

\section{MATERIAL AND METHOD}

In this study, the surgical files of all patients with ASA I and ASA II who underwent septorhinoplasty between 1 January 2019/31 December 2019 in our hospital with local ethical approval (MH 2.1.2020 date 2020/39 number) were analyzed retrospectively. Patients using steroids and antihistamines in the last 24 hours before the operation, patients with ocular pathology were excluded from the study. A total of 721 patients, 403 female, 318 male, were included in the study.

In all patients, anaesthesia was induced with propofol $2 \mathrm{mg} \mathrm{kg}$ and maintained with isoflurane.

It was observed that three different methods were applied in our hospital to protect the eye from possible complications during general anesthesia at various time intervals. The patients were divided into three groups according to the methods used. Patients who undergo eye closure with hypoallergenic surgical tapes (Octamed Fix, Octacare, Turkey) Group I; patients who only used eye ointment with antibiotics (paraffin-based ointment including Terramycine, Pfizer, Turkey) were considered as Group II; and patients with bio-occlusive dressing (Tegaderm ${ }^{\text {twx }}, 3 \mathrm{M}$ Healthcare, Germany) were considered as Group III. The demographic features of the patients, the duration of the operation and the findings or complaints about the eyes, if any, before and after the operation were listed from the surgery and outpatient files. It was investigated whether the frequency of eye complaints and symptoms had a significant difference between patients with different eye protection methods.

\section{Statistical analysis}

Statistical analysis of the data was performed using IBM SPSS for Windows 23.0 (USA) software, and statistical significance was accepted as $\mathrm{p}<0.05$. Chisquare and ANOVA tests were used for statistical evaluation.

\section{RESULTS}

As an eye protection method in 721 patients included in the study, hypoallergenic surgical tape was used to 198 patients, only eye ointment with antibiotics in 302 patients, and bio-occlusive dressing in 221 patients. The demographic characteristics of the groups were as given in Table. There was no statistical difference in terms of demographic data and operation times of the three groups ( $p>0.05)$. A total of $3(0.42 \%)$ patients were found to develop CA. It was determined that two patients in Group I using hypoallergenic surgical tape and one patient in Group II using antibiotic eye pouch were observed to have a sting and rash that did not require treatment on the first day of the operation. These findings evaluated as CA were not statistically significant between the groups $(\mathrm{p}=0.264)$. 


\begin{tabular}{|c|c|c|c|c|}
\hline & $\begin{array}{c}\text { Group } 1 \\
\text { (antibiotic eye ointment) }\end{array}$ & $\begin{array}{c}\text { Group 2 } \\
\text { (bio-occlusive dressing) }\end{array}$ & $\begin{array}{c}\text { Group3 } \\
\text { (hypoallergenic surgical tape) }\end{array}$ & $\mathbf{p}$ \\
\hline Age,year $($ mean $\pm S D)$ & $25.28 \pm 5.70$ & $24.47 \pm 4.84$ & $24.72 \pm 6.32$ & 0.242 \\
\hline Female/male (n) & $130 / 172$ & $98 / 123$ & $90 / 108$ & 0.866 \\
\hline Operation time $(\min )($ mean $\pm S D)$ & $132.61+12.90$ & $132.57+12.59$ & $131.39+12.95$ & 0.534 \\
\hline
\end{tabular}

\section{DISCUSSION}

Corneal abrasion is a condition where the integrity of the cornea is impaired. It facilitates the penetration of pathogenic organisms, which can lead to microbial keratitis and permanent scarring (9). In a meta-analysis in which 16 articles were examined, the most important risk factors for CA formation in non-ocular surgery were stated to be longer surgery $>3.5$ hours, advanced age, Trendelenburg positioning, robotic cases and general anesthesia (10).

Although CA is one of the minor complications of general anesthesia, it can be very painful and adversely affect the patient's hospital stay and surgery experience (11). Surgical drapes, oxygen facial masks and foreign bodies play a role in wear (1).

Longer surgery> It has been shown that after 1 hour of general anesthesia, basic changes occur in the protein content of the tear film layer and the incidence of corneal wear increases (7).

In a study conducted during the years when eye protection methods were not widely used, the incidence of CA was reported to be $44 \%$ (12). The incidence reported in studies conducted after the spread of eye protection methods decreased to numbers such as $0.01 \%-0.11 \%(6,13)$.

Perioperative CAs often occur secondary to insufficient closing of the eyelids (14). During normal sleep, the orbicularis muscle keeps the eyelid closed; general anesthesia prevents contraction (14).

In some studies, tracheal intubation with PEEP increased intraocular pressure. It has been reported to increase the risk of CA in patients with the combined effects of corneal edema and increased intraocular pressure (15).

One-fifth of the peri-operative CAs are directly related to trauma or chemical injury. Accidental spillage of antiseptic or skin cleansing agent (the most common skin antiseptic is povidone-iodine $10 \%$ aqueous solution) into the eyes can cause chemical injury (16).

There is no standard mode of protecting the cornea during general anesthesia for non-eye surgery. The methods described in the literature are not entirely effective and may be associated with undesirable side effects (3).
In a study where eye protection was provided to the study group with ocular tape or ocular ointment and no eye protection method was applied to the control group, $90 \%$ of CA occurred in the control group without any eye protection form. The same study found that the greatest reduction in tear production occurred in the unprotected eye (17).

In a study on corneal protection techniques during non-ocular surgery, simple tape application to closed eyelids has been found to provide equal or superior protection to other interventions such as petroleum jelly application (3).

It has been stated that using lubricants in addition to covering the eyelids and taping does not reduce the risk of CA, but may cause side effects $(18,19)$.

One study has shown that many bands used in the operating room allow chlorhexidine solution to penetrate through the tape, but $3 \mathrm{M}$ Durapore, $3 \mathrm{M}$ Tegaderm Film and Hy-Tape products do not allow fluid to penetrate through the tape (20).

In contrast, in a study of seventy-six patients comparing hydro-gel eye patch and adhesive tape; the authors concluded that the hydro-gel eye patch was superior to the adhesive tape in preventing corneal abrasions (21).

In a study of 72 patients, manual eye closure, adhesive tape, just applying ointment and applying ointment and then applying adhesive tape were compared. The authors reported that in this study, they did not find a significant difference between the groups in CA incidence (22).

In a study where it was stated that the main thing in eye protection was to close the eye completely, Tegaderm ${ }^{\mathrm{TM}}$ Film was suggested to be used in patients at risk of fluids getting into the eyes (23). In one study, it was concluded that horizontal banding had more protective effect than vertical when taping to protect the eye (24).

In another study, the authors stated that they only applied eye ointment to prevent CA (25).

In a study on patients undergoing robotic prostatectomy in the Trendelenburg position, the authors reported that CA did not develop in patients who used Tegaderm during general anesthesia; however, 2.3\% CA developed in patients using a valve banding and ocular lubricant (26). 
In one study, they found that Hypoallergenic tape, paraffin-based ointment including Terramycin, polyacrylic acid liquid gel and Artificial tears including hydroxy- propyl methylcellulose are equally effective in preventing corneal abrasions as an eye protection method (27).

In our study, similar to many publications in the literature, no statistical significance was found between just closing the eye, using antibiotic ointment and using bio-occlusive ( $\mathrm{p}=0.264)$.

Iodine-containing solutions applied to the nose and around the nose to clear the surgical area in septorhinoplasty surgeries may increase chemical injuries in the eyes. We think that the frequency of CA in our study is higher than some studies due to the iodized solution applied to the face. In a study comparing povidone-iodine with isotonic solution, it has been reported that iodized solution can cause minimal corneal damage (28).

The main limitations of our study are that it is retrospective and those eye findings are recorded only due to patient complaints.

\section{CONCLUSION}

Various measures have been taken to prevent corneal abrasion. In rhinoplasty surgery, there is no significant difference between closing the eyelids directly, applying ointment or closing with bio-occlusive material. However, if the patient has a risk of corneal pathology, protection with eyelid banding or lubricating ointment may not be optimal. In such cases, the use of bio-occlusive dressings can be considered.

\section{ETHICAL DECLARATIONS}

Ethics Committee Approval: The study was carried out with the permission of Meltem Hospital Ethics Committee (MH 2.1.2020 date 2020/39 number).

Informed Consent: Because the study was designed retrospectively, no written informed consent form was obtained from patients.

Referee Evaluation Process: Externally peer-reviewed.

Conflict of Interest Statement: The authors have no conflicts of interest to declare.

Financial Disclosure: The authors declared that this study has received no financial support.

Author Contributions: All of the authors declare that they have all participated in the design, execution, and analysis of the paper, and that they have approved the final version.

\section{REFERENCES}

1. Martin DP, Weingarten TN, Gunn PW, et al. Performance improvement system and postoperative corneal injuries: incidence and risk factors. Anesthesiology 2009; 111: 320-6.

2. Morris A, Bonanno L, Bennett M. Effectiveness of corneal abrasion prevention interventions for adults undergoing general anesthesia for more than one hour: a systematic review protocol. JBI Database System Rev Implement Rep 2018; 16: 1785-90.

3. Grixti A, Sadri M, Watts MT. Corneal protection during general anesthesia for nonocular surgery. Ocul Surf 2013; 11: 109-18.

4. Taylor T, Major E. Hazards of reversal of neuromuscular blockade. Hazards and complications of anaesthesia 2nd ed Edinburgh: Churchill Livingstone. 1993: 234-5.

5. Cuddihy PJ, Whittet $H$. Eye observation and corneal protection during endonasal surgery. J Laryngol Otol. 2005; 119: 556-7.

6. Yu HD, Chou AH, Yang MW, Chang CJ. An analysis of perioperative eye injuries after nonocular surgery. Acta Anaesthesiol Taiwan. 2010; 48: 122-9.

7. Anderson DA, Braun TW, Herlich A. Eye injury during general anesthesia for oral and maxillofacial surgery: etiology and prevention. J Oral Maxillofac Surg. 1995; 53: 321-4.

8. Alharethy S, Aldrees T, Aljrid R, Alanazi A, Algaryan SK, Jang YJ. Common nasal deformities among rhinoplasty patients in a university hospital in Saudi Arabia. Ann Saudi Med. 2017; 37: 2017-211.

9. Wilson SA, Last A. Management of corneal abrasions. Am Fam Physician. 2004; 70: 123-8.

10. Papp AM, Justin GA, Vernau CT, et al. Perioperative Corneal Abrasions After Nonocular Surgery: A Systematic Review. Cornea. 2019; 38: 927-32.

11. Moos DD, Lind DM. Detection and treatment of perioperative corneal abrasions. J Perianesth Nurs. 2006; 21: 332-41.

12. Batra YK, Bali IM. Corneal abrasions during general anesthesia. Anesth Analg 1977; 56: 363-5.

13.Segal KL, Fleischut PM, Kim C, et al. Evaluation and treatment of perioperative corneal abrasions. J Ophthalmol. 2014; 2014: 901901.

14. Palte HD. Revisiting perioperative corneal abrasion. ASA Newsletter. 2018; 82: 22-5.

15. White E, Crosse MM. The aetiology and prevention of perioperative corneal abrasions. Anaesthesia. 1998; 53: 157-61.

16. Gild WM, Posner KL, Caplan RA, Cheney FW. Eye injuries associated with anesthesia. A closed claims analysis. Anesthesiology. 1992; 76: 204-8.

17. Grover VK, Kumar KV, Sharma S, Sethi N, Grewal SP. Comparison of methods of eye protection under general anaesthesia. Can J Anaesth. 1998; 45: 575-7.

18. Kaye AD, Renschler JS, Cramer KD, et al. Postoperative Management of Corneal Abrasions and Clinical Implications: a Comprehensive Review. Curr Pain Headache Rep 2019; 23: 48.

19. Snow JC, Kripke BJ, Norton ML, Chandra P, Woodcome HA. Corneal injuries during general anesthesia. Anesth Analg 1975; 54: $465-7$.

20.Reimer C. Eye taping during anesthesia and chlorhexidine exposure. Can J Anaesth 2017; 64: 1159-60.

21. Wan T, Wang Y, Jin X-M. Corneal injury and its protection using hydro-gel patch during general anesthesia. Int J Ophthalmol 2014; 7: 964 .

22. Lee S-J, Im Kim S, Chung JK, et al. Comparison of eye protection methods for corneal abrasion during general anesthesia. Anesth Pain Med 2016; 11: 99-103. 
23. Prakash S. Perioperative eye protection under general anesthesia. J Anaesthesiol Clin Pharmacol 2013; 29: 138.

24. Herbert L. Ophthalmology in anaesthesia and intensive care. Anaesth Intensive Care Med 2004; 5: 304-7.

25. Demir N, Muluk NB, Velentin PT. Anesthesia for Rhinoplasty. All Around the Nose: Springer; 2020. p.783-7.

26. Laverv H, Samadi D, Gainsburg D. 800 preventing ocular injuries during robotic prostatectomy: A simple technique. Eur Urol Suppl 2010; 9: 257.

27. Ganidagli S, Cengiz M, Becerik C, Oguz H, Kilic A. Eye protection during general anaesthesia: comparison of four different methods. Eur J Anaesthesiol 2004; 21: 665-7.

28. Shimmura S, Matsumoto K, Yaguchi H, et al. Acidic electrolysed water in the disinfection of the ocular surface. Exp. Eye Res 2000; 70: 1-6. 